\title{
En åndelig dimensjon er viktig for mange pasienter
}

\author{
Det er nå allment akseptert at sykdom bør forstås ut ifra en biopsykososial modell, der også pasientens \\ tanker, følelser og sosiale relasjoner har betydning. Men livet har også en fjerde dimensjon: det åndelige \\ og eksistensielle. Vi mener at enkle, åpne spørsmål om tro ved anamneseopptak og i andre samtalesitua- \\ sjoner kan bidra til bedre pasientbehandling.
}

\author{
Morten Magelssen \\ magelssen@gmail.com \\ Klinikk for medisin \\ Lovisenberg Diakonale Sykehus \\ 0440 Oslo \\ og \\ Seksjon for medisinsk etikk \\ Universitetet i Oslo
}

Olav Magnus S. Fredheim

Nasjonalt kompetansesenter

for sammensatte lidelser

og

Forskningsgruppe smerte og palliasjon

Institutt for sirkulasjon og bildediagnostikk

Det medisinske fakultet

Norges teknisk-naturvitenskapelige universitet

Den eksistensielle eller åndelige dimensjonen omfatter personens grunnleggende verdier, tanker om hva som gir livet mening, og religiøse eller ikke-religiøse verdensbilde. Dette inkluderer også oppfatninger om hva som skjer etter døden. Målet for denne kronikken er å drøfte om disse sidene ved menneskelivet også er relevant for leger i møte med pasienter og å gi råd om hvordan den åndelige og eksistensielle dimensjonen kan ivaretas.

Internasjonalt er det gjort tallrike studier av samspillet mellom religiøs tro og helse og av pasientenes behov for at helsetjenesten følger opp eksistensielle behov $(1,2)$. Det er imidlertid gjort lite forskning på dette fagfeltet $i$ Norge. Resultatene fra studier som er utført $i$ andre land eller blant pasienter med en spesiell tro, kan ikke ukritisk generaliseres og overføres til andre kulturer og religioner. Det er likevel naturlig å inkludere studier fra andre vestlige land med en kultur og religion som er mye lik vår egen når vi drøfter dette temaet.

\section{Ønske om at åndelige/ eksistensielle temaer tas opp?}

I en studie fra Kreftavdelingen ved Universitetssykehuset Nord-Norge ble 18 pasienter med ikke-kurerbar kreftsykdom intervjuet om sin tro (3). 17 av pasientene fortalte at de trodde på Gud, og 15 at de ba. Intervjuet som ble gjennomført i studien, førte til at fire pasienter ønsket å bli satt i kontakt med sykehusprest, mens to pasienter fikk formidlet kontakt med henholdsvis Frelsesarmeen og Human-Etisk Forbund. Forfatterne konkluderte med at mange pasienter med langtkommet sykdom ønsker at spørsmål om tro blir tatt opp, men at det må gjøres med respekt og på pasientens premisser. Studien viser også at det ikke bare er pasienter med religiøst livssyn som kan ha behov for å samtale om livssynet sitt.

I en annen norsk studie utført i en uselektert populasjon av kreftpasienter ved ulike kreftavdelinger, fylte 642 pasienter ut et spørreskjema om alternativ behandling (4). I studien inngikk fem spørsmål om religiøsitet. Av de 600 som besvarte spørsmålet, vurderte $246(41 \%)$ av pasientene seg som «troende», 236 (39\%) som «ikketroende», mens de resterende var usikre. Knapt halvparten av pasientene i studien mente at pasienter i deres situasjon burde tilbys kontakt med prest.

I en annen norsk spørreskjemastudie ble 183 pasienter behandlet for Hodgkins sykdom ved Oslo universitetssykehus, Radiumhospitalet stilt 45 spørsmål om religion (5). 107 (58\%) svarte, hvorav $32(30 \%)$ regnet seg som religiøse/troende. 40 pasienter (37\%) anga at de hadde endret sin tro som følge av sykdommen, hvorav de fleste (33 av de 40) var blitt mer troende. 58 pasienter $(54 \%)$ hadde bedt til Gud om helbredelse. Halvparten oppga at de ikke syntes tilbudet om sjelesorg under sykehusoppholdet var tilfredsstillende.

I en spørreskjemabasert studie fra en lungepoliklinikk ved et amerikansk sykehus ble 177 pasienter spurt om religiøsitet og sykdom (6). Halvparten av pasientene beskrev seg selv som religiøse, og hele $90 \%$ rapporterte at de trodde at bønn i noen tilfeller kunne påvirke utfallet av sykdom. To tredeler av pasientene ga uttrykk for at de ville sette pris på spørsmål om hvorvidt de hadde en religiøs tro når anamnesen ble tatt opp, mens $16 \%$ ikke ønsket dette. Imidlertid var det kun $15 \%$ av pasientene som hadde erfart å bli spurt om hvorvidt de hadde en tro som ville påvirke deres medisinske avgjørelser, som for eksempel ved spørsmål om livsforlengende behandling.

\section{Livssyn påvirker behandlingspreferanser}

Pasientens livssyn kan ha betydning for pasientens behandlingspreferanser. Dette gjelder særlig beslutninger ved livets slutt. I en studie fra en amerikansk lungepoliklinikk hevdet $45 \%$ av pasientene at deres religiøse tro ville påvirke beslutninger om behandling ved alvorlig sykdom (6). Religiøse forestillinger kan også påvirke pasienters etterlevelse av medisinske behandlingsråd. Et kjent eksempel er Jehovas vitner som reserverer seg mot blodtransfusjon.

\section{Eksistensielle kriser og religiøse mestringsstrategier} Ved alvorlig sykdom stiller både religiøse og ikke-religiøse pasienter seg spørsmål om meningen med det de gjennomgår. Dette kan utfordre deres eksistensielle verdensbilde og innebære en eksistensiell krise med behov for samtale med en trosfelle eller åndelig veileder. I en kvalitativ studie i Storbritannia ble 45 kreftpasienter intervjuet om hvordan de fortolket smertene ved kreftsykdommen (7). To grupper opplevde at smerten henholdsvis var uttrykk for at Gud ville teste troen deres, som i historien om Job i Bibelen (8), og at smerten var uttrykk for guddommelig straff.

Religiøs mestring er anvendelse av religiøse oppfatninger eller religiøs praksis for å redusere følelsesmessig stress og lidelse. Dette er særlig studert hos pasienter med kronisk smerte (9). Blant de positive religiøse mestringsstrategiene er lesing av religiøse tekster, åndelig støtte, deltakelse i religiøse møter eller ritualer, hjelp til å tilgi og det å lære mestring av åndelige rollemodeller. Negative religiøse mestringsstrategier kan være å se på smerte som guddommelig straff og fokusere på demoner som årsak til sykdom. I en del forskningslitteratur kategoriseres bønn som en passiv og uhensiktsmessig mestringsstrategi, men 


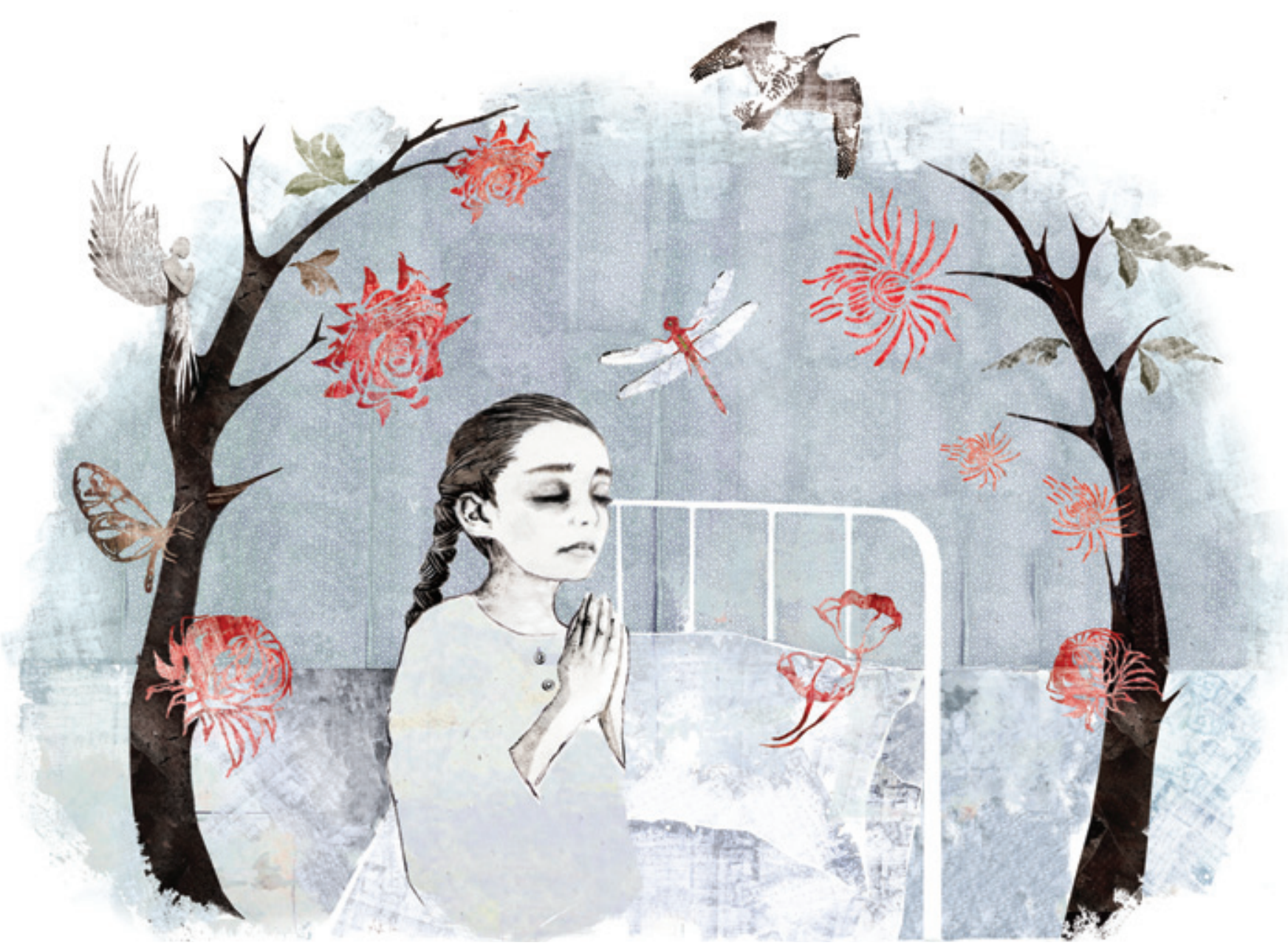

Illustrasjon Elin Karlsnes

nyere forskning tyder på at bønn i mange tilfeller er en aktiv og tjenlig strategi (9). Vi mener derfor at en kartlegging og vurdering av eventuelle religiøse mestringsstrategier er relevant i denne pasientgruppen.

\section{Skyldfølelse og forsoning}

En kvalitativ studie av 23 svenske pasienter med kronisk obstruktiv lungesykdom viste at et av temaene som opptok disse pasientene mest, var skyldfølelse knyttet til at sykdommen var selvpåført på grunn av røyking (10). Selv om tilsvarende data ikke er tilgjengelig for andre sykdommer, er det grunn til å anta at skyldfølelse også kan være en viktig faktor hos andre pasienter med livsstilsrelaterte sykdommer. Fordi en økende andel av sykdommene i befolkningen er livsstilsrelaterte, bør grad av skyldfølelse og dens betydning for pasienten kartlegges. Skyldfølelsen kan være knyttet både til relasjonen til familie og nærstående og til relasjonen til det guddommelige. Så vel skyldfølelse som andre faktorer kan ha skadet pasientens relasjoner. Når viktige relasjoner er skadet, vil pasienten være tjent med gjenoppretting gjennom forsoning. Helsetjenesten kan bidra ved å hjelpe pasienten til å identifisere og anerkjenne problemet slik at forsoningsprosessen kan starte.

\section{Sammenheng mellom religion og helse?}

Sammenhengen mellom religiøsitet og somatisk helse er forsøkt undersøkt empirisk $i$ en rekke studier $(1,2,11)$. De fleste av dem er gjennomført i den vestlige verden på pasienter med en kristen tro, og flere metodologiske forhold gjør det vanskelig å påvise årsakssammenhenger. En gjennomgang av feltet påviste at kun én av ni hypoteser om sammenhenger hadde støtte i forskningen, nemlig en hypotese om at hyppig deltakelse på religiøse møter er assosiert med redusert dødelighet (2). Selv om det er avdekket sammenheng mellom aktiv religiøsitet og god helse i den generelle befolkningen, er det ikke i prospektive studier av pasientgrupper funnet at religiøsitet i seg selv øker overlevelse.

\section{Åndelig anamnese}

Åndelige og eksistensielle temaer er altså viktige for mange pasienter med alvorlig sykdom, og noen pasienter ønsker at slike temaer tas opp av leger og annet helsepersonell. Vi mener det i noen tilfeller er tjenlig at legen kartlegger pasientens åndelige situasjon gjennom en enkel «åndelig anamnese». Legen kan for eksempel spørre om pasienten har en religiøs tro, om livssynet innvirker på pasientens evne til å mestre pågående sykdom, om trosoppfatningene spiller en rolle for valg av behandling samt om pasienten ønsker kontakt med sykehuspresten eller annen åndelig veileder. Det er viktig at legen ikke presser sin egen tro på pasienten. Åndelige temaer må kartlegges med følsomhet når det gjelder pasientens ståsted og med respekt for pasientens ønsker. I praksis kan åndelig anamnese være tidkrevende. Videre kan det være en utfordring at leger ikke har profesjonell kompetanse i å kartlegge og håndtere eksistensielle temaer.

En åndelig anamnese vil ved mange pasientkontakter ikke være relevant. Avhengig av situasjon og problemstilling må legen evne å skifte mellom en reduksjonistisk og symptomfokusert tilnærming og en holistisk tilnærming som inkluderer det åndelige og eksistensielle. Vi mener en åndelig anamnese spesielt har sin plass hos pasienter med alvorlig sykdom, begrenset forventet levetid, eller kronisk sykdom med stor funksjonssvikt eller høy symptomintensitet. I tillegg er det tjenlig ved innleggelse i sykehus eller sykehjem og før større operasjoner. Åndelig anamnese kan noen ganger styrke lege-pasient-forholdet, ved at det øker pasientens opplevelse av å bli ivaretatt som et helt menneske. 
Legen kan velge å følge opp eksistensielle aspekter ved pasientens sykdom selv eller overlate det til sykepleier eller andre $\mathrm{i}$ behandlingsteamet. En avklaring med spørsmålet «Hvem har vært til hjelp for deg tidligere?» kan ofte identifisere ressurspersoner som familiemedlemmer, venner, prest på hjemsted eller andre som kan trekkes inn. Dersom pasienten og legen deler samme tro og etablerer et åndelig fellesskap, må det være på pasientens premisser, for legen skal være lege og ikke sykehusprest.

Oppgitte interessekonflikter: Forfatterne er aktive i Norges kristelige legeforening.

\section{Litteratur}

1. McCullough ME, Hoyt WT, Larson DB et al. Religious involvement and mortality: a meta-analytic review. Health Psychol 2000; 19: 211-22.

2. Powell LH Shahabi L, Thoresen CE. Religion and spirituality. Linkages to physical health. Am Psychol 2003; 58: 36-52.

3. Norum J, Risberg T, Solberg E. Faith among patients with advanced cancer. A pilot study on patients offered «no more than» palliation. Support Care Cancer 2000; 8: 110-4.

4. Risberg T, Wist E, Kaasa S et al. Spiritual healing among Norwegian hospitalised cancer patients and patients' religious needs and preferences of pastoral services. Eur J Cancer 1996; 32: 274-81.

5. Torbjørnsen T, Stifoss-Hanssen H, Abrahamsen A et al. Kreft og religiøsitet - en etterundersøkelse av pasienter med Hodgkins sykdom. Tidsskr Nor Lægeforen 2000; 120: 346-8.

6. Ehman J, Ott B, Short T et al. Do patients want physicians to inquire about their spiritual or religious beliefs if they become gravely ill? Arch Intern Med 1999: 159: 1803-6.

7. Koffman J, Morgan M, Edmonds P et al. «l know he controls cancer»: The meanings of religion among Black Caribbean and White British patients with advanced cancer. Soc Sci Med 2008; 67: 780 -9.

8. Bibelen. Job 1,8-22

9. Wachholtz A, Pearce M. Does spirituality as a coping mechanism help or hinder coping with chronic pain? Curr Pain Headache Rep 2009; 13 127-32.

10. Lindqvist $G$, Hallberg L. Feelings of guilt due to self-inflicted disease: a grounded theory of suffering from chronic obstructive pulmonary disease (COPD). J Health Psychol 2010; 15: 456-66

11. Hummer R, Rogers R, Nam C et al. Religious involvement and US adult mortality. Demography 1999; $36: 273-85$.

Mottatt 31.8. 2010, første revisjon innsendt 23.9. 2010, godkjent 7.10. 2010. Medisinsk redaktør Mette Sagsveen. 